\title{
Perception of Mobbing by Teachers and Organizational Depression: A Correlational Model Study
}

\author{
Esef Hakan Toytok
}

Department of Educational Sciences, Faculty of Education, Siirt University, Turkey

Copyright $\bigcirc 2017$ by authors, all rights reserved. Authors agree that this article remains permanently open access under the terms of the Creative Commons Attribution License 4.0 International License

\begin{abstract}
As is known, mobbing (intimidation) is an important concept being subject to many researches in numerous fields and many researchers suggest that this concept has the power to directly affect organizational

positive significant relationship between mobbing and organizational depression. The regression analysis shows that more than $15 \%$ of depression in an organization can be attributed to mobbing.
\end{abstract} structures. Even though the concept of mobbing changes from country to country, culture to culture and organization to organization, it is seen that its consequences in terms of employees are the same. It is also seen in researches that the most recent concept in studies to improve organizational effectiveness is organizational depression and it directly affects operability and functionality of organization. As in mobbing, there are depressive symptoms of organizational depression such as decrease in performance, lack of communication, motivation and unhappiness. Therefore, this research aims to clarify the concepts of mobbing and organizational depression, which affect organizational functioning and achieving organizational objectives to this extent to determine mobbing and perception levels of organizational depression to teachers who have vital importance for educational organizations and which are exposed to in terms of various variables and to reveal the relationship and impact of these perception levels. Descriptive Relational Screening Model, a quantitative research method, is used for this research. The universe of the research is composed of 1642 teachers working at primary, secondary and high schools in the center of Siirt province and its sample includes 386 randomly selected teachers. The obtained data are entered into SPSS 21 packaged software and the appropriate statistical analysis procedure is adopted. The findings obtained as the result of statistical processes are tabulated, analysed and interpreted. According to the results based on the obtained findings in the research, teachers are not exposed to high-level mobbing and organizational depression. No significant difference is seen in their perception of mobbing and organizational depression in terms of independent variables such as marital status, gender, and professional seniority but there are significant differences for mobbing in independent variables of school types and branches and for organizational depression in the variable of country's states. It is seen in the research that there is a medium level and

Keywords Organization, Mobbing, Organizational Depression

\section{Introduction}

Individuals spend a great part of their lives within the organization they work for and as part of the said organization. During this period, they communicate, create impact or are affected within their organization. Recent researches revealed that the concept of mobbing (psychological intimidation) became prominent as one of the conditions which caused high level of negativity on people at their workplaces. Mobbing is defined by associating it with concepts like intentionally and systematically mistreating someone most of the time, being aggressive to, abusing, humiliating and psychologically tormenting him/her (Moayed et al., 2006; Griesser, 2005; Einarsen, 1999; Gündüz and Yılmaz, 2008; Cemaloğlu, 2007; Tinaz, 2006; Arpacioğlu, 2003). However, the concept of mobbing was clearly defined for the first time by Leymann (1996) as one or rarely more than one individuals being systematically exposed to emotionally harmful acts via psychological harassment in the workplace every day for a couple of months by one or more than one individuals. Turkish equivalent of mobbing is defined by Turkish Linguistic Society as "emotional harassment, in-office emotional harassment, organizational oppression, psychological harassment, emotional bullying, psychological terror, emotional assault, in-office bullying" (TLS, 2005). Due to their structures, organizations witness numerous types of conflicts either explicit or implicit. These conflicts often lead to stress and anxiety of the employees in the organization. In recent years, this conflict and intimidation by harassment experienced particularly in developed countries is named as mobbing (Çobanoğlu, 2005). The concept of mobbing has been subject to 
researches in different organizations and still is together with many variables such as leadership styles, organizational commitment, burnout, job satisfaction and motivation. It is known that performances of an individual or of individuals who are exposed to mobbing show a decrease. Consequently, breakdowns in relationships and communication within the organization, failures in organizational functionality and growing away from the objective may occur. Once again, we see that there is another concept which is closely related to organizational health and effectiveness which also became prominent recently and it is called organizational depression. Being actually defined as a clinical disorder, depression is a psychological disorder which deeply disturbs the life of an individual in almost every respect such as business, family, and social life. Likewise, organizational depression causes negative attitude of employees towards their organization. Today, studies intending to create effective organizations are increasing in number every passing day. In recent years some researchers in our country also began to examine the concept of organizational depression to which individuals are frequently being exposed especially in fields requiring one-to-one relations between individuals such as healthcare, security and education (Sağır, 2015; Aslan, Aslan, Göksoy and Sağır, 2014; Bakan, Taşlıyan and Aka, 2014; Sezer, 2011; Sezer, 2010; Aydın, 2010; Gümüştekin and Öztemiz, 2004; Y1lmaz and Ekinci, 2003). Bilchik (2000) defined organizational depression as "inactivity spread over the organization, getting stuck, generally not planning the future, not having a vision with regard to what they will do in the future and giving up trying". Beck and Alford (2009) defined personal symptoms of depression as an apparent change in the mood of an individual, sadness, loneliness, self-reproach, regression, self-punishment tendency, evasion, hiding or wishing to be dead. Consequently, the depressed individual cannot go on working, stop contacting with his or her social environment and gradually withdraws into himself/herself more and more (Sezer, 2011). Dökmen (2014) defined its indications with regard to the organization in his research as resistance to innovation and change, gradually increasing miscommunication between employees and management, widespread negative hearsay about the workplace and noticeable decrease in maintenance and cleanness of the workplace. As it is understood, it is seen that there is a causative and resultative relationship between mobbing and organizational depression. Obviously, the most common organization type is school among public organizations in our country. Schools are social and open systems in terms of their organizational structure and they affect other formal and informal organizations around them (Uğurlu, 2015). Therefore the purpose of this research is determining the relationship between mobbing and organizational depression and the impact of mobbing experienced by teachers on organizational depression. In line with this purpose, answers have been sought to following questions in our research;
1. What is the extent of mobbing they experience according to perceptions of teachers?

2. What is the extent of perception of teachers with regard to organizational depression?

3. What is the relationship between the extent of mobbing experienced by teachers and organizational depression?

\section{Method}

This research aims to determine the relation of teachers with mobbing and organizational depression. Descriptive Relational Screening Model, a quantitative research method, is used in the research. In Descriptive Relational Screening researches, a circumstance or event is described as is and the impacts and extents of causes leading to this circumstance or event are determined (Kaya, Balay and Göçen, 2012). The universe of the research is composed of 2083 teachers working in primary, secondary and high schools in the center of Siirt province. Since kindergartens, counseling and research centers, science and art centers and private educational institutions are not included in the research, the universe type used is the realistic universe. The realistic universe is the universe constituted by these searcheres by taking some certain limitations into consideration (Altunışık, Coşkun, Yıldırım, and Bayraktaroğlu, 2002). It is considered that the universe of research is heterogeneous, that is it includes different ideas and opinions and thus it is accepted that $\mathrm{p}=0.5$ and $\mathrm{q}=0.5$. So it was calculated pursuant to the formula found by Yazicioğlu and Erdoğan (2004) and 363 teachers were selected randomly. Information about the sample is presented in Table 1.

Table 1. Information on sample of research

\begin{tabular}{cll}
\hline & $\mathrm{N}$ & $\%$ \\
\hline Type of School & 141 & 35.2 \\
Primary school & 180 & 45.0 \\
Middle School & 79 & 19.8 \\
High School & & \\
Field of Study (Branch) & 119 & 29.8 \\
Grade & 281 & 70.2 \\
Field of Study (Branch) & & \\
Occupational Seniority & 197 & 49.2 \\
5 years and below & 101 & 25.3 \\
6-10 years & 102 & 25.5 \\
11 years and above & & \\
Married & 251 & 62.8 \\
Single & 149 & 37.2 \\
Marital Status & & \\
Male & 217 & 54.2 \\
Female & 183 & 45.8 \\
Gender & & \\
Siirt & 231 & 57.8 \\
Other & 169 & 42.2 \\
Yes & & \\
No & 244 & 61.0 \\
Total & 156 & 39.0 \\
\hline Union Membership & 400 & 100 \\
\hline
\end{tabular}


As data collection tools, 24-point Mobbing Scale developed by Cemaloğlu (2007) and 42-point organizational depression scale developed by Sezer (2011) are used in research. The data obtained are converted into a data set by In R. 3.3.1 (R Core Team, 2016) program and validity and reliability studies of the scales are made. Arithmetic means, standard deviations, and percentage values of data are used in research. Correlation and regression analysis procedure is applied to determine the relationship between variables.

Cronbach Alpha value for the mobbing scale used in research is taken as $=.93$, Cronbach Alpha value for organizational depression scale $\alpha=.90$. Reliability values of both scales are found very high. Confirmatory factor analysis (CFA) is made for the validity of scales used in research. According to results of CFA, it is seen that the variance value of mobbing scale is approximately $53 \%$ and of organizational depression scale was approximately $41 \%$.

\section{Findings}

Perceptions of mobbing by teachers participating the research are presented in Table 2.

Table 2. Perception of mobbing by teachers

\begin{tabular}{|c|c|c|}
\hline 1. Some people hide information that would affect your success from you & 4.51 & 0.76 \\
\hline 2. You will be humiliated by making you work below your level of competence. & 4.65 & 0.72 \\
\hline 3. You are asked to perform works below your level of competence. & 4.53 & 0.79 \\
\hline 4. Your responsibilities in important fields are removed or replaced with less important and undesirable tasks. & 4.57 & 0.81 \\
\hline 5. Gossips and rumors spread about you. & 4.50 & 0.80 \\
\hline 6. You are ignored, alienated or paid no attention. & 4.64 & 0.70 \\
\hline 7. Your personality (eg, habits and good manners), attitude or private life are insulted and humiliated. & 4.74 & 0.69 \\
\hline 8. You will be shouted at or you will be the target of instant anger (or ambition). & 4.70 & 0.71 \\
\hline 9. You are exposed to threatening behaviors such as pointed at, assault to personal area, pushing and waylaying. & 4.76 & 0.67 \\
\hline 10. Others imply you to quit the job. & 4.74 & 0.65 \\
\hline 11. Your mistakes and faults are being repeatedly reminded and mentioned. & 4.60 & 0.76 \\
\hline 12. Your approaches are disregarded or ignored. & 4.54 & 0.82 \\
\hline 13. You are confronted with hostile reactions. & 4.64 & 0.80 \\
\hline 14. There are endless criticisms about your work or your efforts. & 4.57 & 0.77 \\
\hline 15. Your ideas and opinions are disregarded. & 4.60 & 0.89 \\
\hline 16. Persons you don't get along with crack jokes (practical jokes) that you don't like. & 4.68 & 0.72 \\
\hline 17. You are assigned to unreasonable or impossible-to-complete jobs. & 4.63 & 0.76 \\
\hline 18. You are blamed and tested. & 4.67 & 0.77 \\
\hline 19. Your works are excessively supervised. & 4.52 & 0.81 \\
\hline 20. You are pressurized not to demand some of your rights (such as sick leave, holiday entitlement, travel allowance). & 4.64 & 0.80 \\
\hline 21. You are subject to extreme mockery and teasing. & 4.79 & 0.58 \\
\hline 22. You will be exposed to the workload that you cannot overcome. & 4.68 & 0.71 \\
\hline 23. You are subject to violence, physical or psychological abuse. & 4.75 & 0.69 \\
\hline $\begin{array}{l}\text { 24. Have you ever exposed to bullying (intimidation) at the workplace? (Appraise it in terms of definition: Bullying is a } \\
\text { situation where one or more individuals have been performing for a certain period of time towards somebody and } \\
\text { consequently, the individual who is exposed to it perceives that he/she is exposed to unfavorable behaviors and has difficulty } \\
\text { to protect himself/herself against these actions. Incidents that occurred just once and not repeated are not bullying. }\end{array}$ & 4.76 & 0.66 \\
\hline General Average & 4.64 & 0.76 \\
\hline
\end{tabular}

When Table-2 is examined, it is seen that average scores of teachers about mobbing they experience are close to each other. Averages change between $\bar{X}=4.50$ and $\bar{X}=4.79$. When findings are examined, we see that general average of teachers' perception of mobbing is 4.64 . Our scale corresponds to the values of $\bar{X}=1.00-1.80)$ 'everyday', $(\bar{X}=$ 1.81-2.60) 'once a week', ( $\bar{X}=2,61-3,40)$ 'once a month', $(\bar{X}=3,41-4,20)$ 'sometimes' and ( $\bar{X}=4,21-5.00)$ 'never'. When we examine our finding, the arithmetic average is 4.64 and this refers to 'never'. The measurement results show that teachers' level of experiencing mobbing are low. When the table is examined, most of the teachers stated that they are intimidated by gossips about them $(\bar{X}=4.50)$. These findings are followed by "Some people hide information that would affect your success from you" ( $\bar{X}=4.51)$ and "Your works are excessively supervised" ( $\bar{X}=4.51)$. "You are subject to extreme mockery and teasing" is the lowest of a variable" $(\bar{X}=4.79)$. This is followed by $(\bar{X}=4.76)$ "You are exposed to threatening behaviors such as pointed at, assault to the personal area, pushing and waylaying". High values of gossip and excessive supervision might be explained with a widespread of such a culture in our community. It could be said that the highness of this value might be a result of the opinion that teachers would be forced to do something by pressurizing and inflicting violence through traditional ways of supervision. When answers of our teachers are assessed, the reasons for the low-level physical violence might be the fact that teachers are setting an example for students as being soldiers of education, teaching is a public profession, the nature of the profession is determined by laws and physical violence is 
constitutionally a crime to be punished. Because even though the punishment for physical violence is determined by laws in our country, there is no direct provision with regard to intimidation. In order for teachers not to be exposed to intimidation by "hiding information that would affect success", teachers might be informed regarding announcements about in-service training or graduate studies. In order for teachers not to be exposed to intimidation by "widespread gossip and rumors about them", social events might be organized to increase unity and solidarity among them and an intimate and warm environment might be provided to prevent gossips. When standard deviation values of research are examined we see that the highest value of standard deviation (0.89) corresponds to point 15 , which is "our ideas and opinions are disregarded" and teachers constituted a heterogeneous group by giving different answers to this question. We see that teachers have a difference of opinion with regard to this issue. The lowest value in our research corresponds to point 10 , which is "others imply you to quit the job." The standard deviation of this point is 0.65 and we see that our teachers establish a homogeneous structure and give common answers.

The perceptions of teachers regarding organizational depression are presented in Table 3.

Table 3. Organizational depression levels of teachers

\begin{tabular}{|c|c|c|}
\hline & $\bar{X}$ & S.s. \\
\hline 1. Constructive solutions are found within my institution. & 2.46 & 1.51 \\
\hline 2. Employees' opinions are respected. & 2.26 & 1.13 \\
\hline 3. Interpersonal communication is destructive rather than constructive. & 2.12 & 2.93 \\
\hline 4. Employees are generally exhausted. & 2.58 & 1.28 \\
\hline 5. Tasks, authorities, and responsibilities of employees are unclear. & 2.26 & 1.25 \\
\hline 6. My institution is open to innovations. & 2.64 & 2.96 \\
\hline 7. Employees are encouraged and rewarded. & 3.16 & 1.28 \\
\hline 8. Before a decision is made, opinions of employees at every level are asked and they are evaluated. & 2.87 & 1.25 \\
\hline 9. I feel valuable and lucky for working at this institution. & 2.55 & 1.30 \\
\hline 10. Employees are hopeless about the future of the institution. & 2.50 & 1.29 \\
\hline 11. Employees work zestfully. & 2.79 & 1.22 \\
\hline 12. The opinion of management always prevails. & 2.85 & 1.34 \\
\hline 13. Different opinions are opposed. & 2.41 & 1.19 \\
\hline 14. My institution is constantly developing and progressing. & 2.90 & 2.30 \\
\hline 15. Problems of employees are immediately taken care of and tried to be resolved. & 2.61 & 1.20 \\
\hline 16. Most of the employees are not fond of their works. & 2.49 & 1.19 \\
\hline 17. Employees cannot exactly do their real jobs as they deal with unnecessary tasks. & 2.29 & 1.21 \\
\hline 18. Most of the employees are unhappy at the workplace. & 2.51 & 1.24 \\
\hline 19. Employees help each other for their development. & 2.45 & 1.15 \\
\hline 20. Our work environment is constantly improved. & 2.62 & 1.17 \\
\hline 21. Changes at my institution are promising. & 2.70 & 1.24 \\
\hline 22. Physical conditions at my institution are neglected. & 2.74 & 1.35 \\
\hline 23. My institution is convenient to learn new things. & 2.73 & 1.29 \\
\hline 24. My institution cannot develop due to bureaucratic obstacles. & 2.66 & 1.31 \\
\hline 25. Development plans are made and applied at my institution. & 2.73 & 1.21 \\
\hline 26. Needs of employees are tried to be met at my institution. & 2.57 & 1.15 \\
\hline 27. Employees work in accord and cooperation with the administration. & 2.40 & 1.20 \\
\hline 28. Management does not treat employees equally. & 2.35 & 1.29 \\
\hline 29. Employees are open to listening to the problems of students. & 2.30 & 1.25 \\
\hline 30. Most of the employees don't want to take on additional responsibilities. & 2.74 & 1.29 \\
\hline 31. The administration uses all amenities to improve the abilities and skills of employees. & 2.79 & 1.25 \\
\hline 32. Works progress so slowly at my institution. & 2.46 & 1.23 \\
\hline 33. I am happy with working conditions. & 2.67 & 1.32 \\
\hline 34. Policies and procedures are always complied with at my institution. & 3.45 & 1.19 \\
\hline 35. Assessments are based on my performance. & 2.66 & 1.20 \\
\hline 36. Employees are mostly late to work. & 2.29 & 1.21 \\
\hline 37. Ideas and projects of employees are heard and supported by the administration. & 2.58 & 1.23 \\
\hline 38. Employees resist changing. & 2.50 & 1.22 \\
\hline 39. Performance of employees is low. & 2.29 & 1.21 \\
\hline 40. I regularly receive feedback about the quality of my performance. & 3.00 & 1.18 \\
\hline 41. In the case of a conflict, everybody blames each other. & 2.35 & 2.86 \\
\hline 42. Innovations are followed at my institution. & 2.65 & 1.31 \\
\hline General Average & 2.59 & 1.39 \\
\hline
\end{tabular}


When Table- 3 is examined it is seen that average scores show a heterogeneous distribution with regard to organizational depression experienced by teachers. Averages change between $\bar{X}=2.12$ and $\bar{X}=3.45$. When results are examined we see that average perception of organizational depression by teachers is 2.59 . Our scale corresponds to the values of $\bar{X}=1.00-1.80$ ) 'exactly appropriate', ( $\bar{X}=1.81-2.60)$ 'fairly appropriate', $(\bar{X}=$ $2,61-3,40)$ 'neutral', ( $\bar{X}=3,41-4,20)$ 'not very appropriate' and ( $\bar{X}=4,21-5.00)$ 'not appropriate'. When we examine our finding, the arithmetic average is 2.59 and this refers to 'exactly appropriate'. The results show that organizational depressions are not high. Research reveals that value of point 34 of our research, "policies and procedures are always complied with at my institution is $\bar{X}=3.45$ and it means "not very appropriate". Point 34 shows that policies and procedures are not complied with at the institution. This result might be caused by reduced supervision of inspectors, especially in eastern provinces in recent years. The principals appointed to schools become managers via the union they are a member of, even though they don't have any accumulation of knowledge and they try to manage the schools without knowledge of legislation and with limited information as they are not trained on policies and procedures to be applied. As a result, they confer their own responsibilities to employees and this might lead to unproductive work of teachers and organizational depression. Point 34 is followed by point 7 which is "employees are encouraged and rewarded" with the value of $\bar{X}=3.16$ which corresponds to "neutral". Teachers might have thought that reward system does not work well in national education. 3rd point of our research, which is "interpersonal communication is destructive rather than constructive" has a low value and arithmetic average is 2.12, that is "fairly appropriate". Interpersonal communication is not considered as destructive. Constructive relations can be exhibited in bilateral relations as managers are untrained and uninformed and not being able to apply legislation and their powers at the results of bad situations. 3rd point of our research, followed by point $2(\bar{X}=2.26)$ which is "employees' opinions are respected" and point $5 \bar{X}=2.26$ ) which is "Tasks, authorities, and responsibilities of employees are unclear." We see that these points are "fairly appropriate" $\bar{X}=$ $1.81-2,60)$. It is thought that opinions of employees are respected and there is no uncertainty of tasks. When we look at the standard deviation of our research, we see that point 6 , that is 'institution is open to innovations' $(\mathrm{S} . \mathrm{s}=2.96)$ has a heterogeneous structure. Teachers gave varying answers to the question of openness of institution to innovations. When we look at the point with lowest standard deviation, we see that point 2, "opinions of employees are respected" has a homogeneous structure and this means that teachers state that their opinions are respected.

In compliance with perceptions of participating teachers, findings regarding the relationship between mobbing and organizational depression are presented in Table 4.

Table 4. Correlation of mobbing and organizational depression

\begin{tabular}{lcc}
\hline & Mobbing & $\begin{array}{c}\text { Organizational } \\
\text { Depression }\end{array}$ \\
\hline Mobbing & 1 & 1 \\
Organizational Depression & $.390^{* *}$ & 1 \\
\hline Significant difference is sought for $* \mathrm{p} \leq .05$ and $* * \mathrm{p} \leq .01$.
\end{tabular}

When the data in Table 4 are examined, it is seen that there is a medium level and positive significant relationship between mobbing and organizational depression $(\mathrm{R}=.39)$. According to Köklü, Büyüköztürk and Çokluk, (2007) if (p $\leq .0199 \%$ reliability $\mathrm{R}$ value $.01-.29$, low, if between .30-.69, medium and if it is between .70-.99, there is a high level of relationship. Accordingly, it can be said that as mobbing at the schoolsincreases, organizational depressions also increases and if mobbing decreases, organizational depression would also decrease.

The regression of predictor variable, mobbing and dependent variable, organizational depression by participating teachers are presented in Table 5.

When the data in Table 5 are examined, it is seen that there is a significant explanatoriness between the predictor variable, mobbing and dependent variable, organizational depression. Pursuant thereto approximately $15 \%$ of depression $\left(\mathrm{r}^{2}=, 152\right)$ in an organization is explained by mobbing. When other values are examined, the values of $\beta$ $=-.390, \mathrm{~F}=71.259$ and $\mathrm{P}=.000 * *$ supports the importance of this relationship. There are many variables affecting the emergence of organizational depression at a school. In this respect, we see that mobbing has an important share on organizational depression. Psychological and biological aspects of mobbing verify this relationship. Making teachers do things below their competence level and disregarding their opinions make teachers feel worthless. Attitude and behaviors of administrators, that is favoring some persons, not establishing a teacher-manager relationship, the administration's regarding teachers as their competitors and pushing teachers around in contemplation of losing authority cause teachers to be alienated from their profession and this affects the work environment. Any problem in work environment might affect the school and cause it fall into depression. Communication disorder at a school, problems among teachers, pressurizing each other directly make teachers mentally depressed and so organization becomes unproductive. Becoming unproductive and losing its objective, organization falls into depression. 
Table 5. Regression results regarding mobbing and organizational depression

\begin{tabular}{lccccc}
\hline & \multicolumn{3}{c}{ Explanatory variable: Mobbing } \\
\hline Explained variable: Organizational Depression & $\mathrm{F}$ & $\beta$ & $\mathrm{r}^{2}$ & $\mathrm{p}$ \\
\cline { 2 - 5 } & & 71,259 &,- 390 &, 152 &, $000^{* *}$ \\
\hline
\end{tabular}

Significant difference is sought for $* \mathrm{p} \leq .05$ and ${ }^{* *} \mathrm{p} \leq .01$.

\section{Discussions, Conclusions and Recommendations}

It was tried to determine the extent of mobbing to the degree of the perceptions of teachers working at schools in the center of Siirt province and the level of its impact on organizational depression via results of research. When the level of perception of teachers with regard to mobbing is examined, it is seen that the behaviors mentioned at most are "there are rumors about them", "some people hide information that would affect their success from them" and "excessive supervision of their works". It is seen that the same intimidating behaviors are found in different researches. For example; 'widespread gossip and rumor about them' (Okçu, 2011; Ertürk, 2005; Mammadov, 2010), 'disregarding their ideas and opinions' (Kılınç, 2014; Yumuşak, 2013; Aras, 2012; Ertürk, 2005) and 'someone's hiding information that would affect success' (Mammadov, 2010; Okçu, 2011). When this is examined in terms of some variables, we see that classroom teachers are exposed to mobbing more than branch teachers. The same finding is identified in studies of Eğerci (2009) and Ural (2009). The factors affecting this result might be high expectations from branch teachers, the obstacle called TEOG exam that middle school students meet with and the desire of school principals to educate their students to be able to enroll good schools such as Science High School. Of course, this leads to increase in expectations from branch teachers.

It is determined that there is a medium level and positive significant relationship between the perception levels of participating teachers with regard to mobbing and organizational depression. Accordingly, when mobbing increases at schools, the level of organizational depression also increases. When the causes are examined, it is confirmed that effects of mobbing experienced by teachers first reflects on themselves and then on their professional life, i.e. school environment. This negativity felt at school also affects other teachers and creates a basis for organizational depression. As a result, teachers who are exposed to mobbing begin feeling that they don't belong to that school and worthless. Anotherresult obtained from this research is that mobbing significantly explains organizational depression. This indicates that mobbing behaviors in an organization affect organizational depression to a great extent. These problems experienced in work environment affect the school and make it fall into depression. Consequently, this situation directly affects teachers, they become mentally distressed and at the end, the organization becomes unproductive. Organizations which become unproductive and lose their objectives fall into depression.

Eventually, mobbing and organizational depression make individuals become isolated, be detached from social life, lose self-confidence and self-respect. They also lead to psychological and psychosomatic disorders and in terms of organization, reduced performance, withdrawing themselves and quitting the job. As a matter of course, these states don't come to light suddenly. They gradually progress and inflict deep and permanent wounds in social life. When it comes to organizations, it leads to loss of labor and qualified employees, increase in expenses like treatment, accidents and compensations, reduction in organizational effectiveness. Basing on their researches Hoel et al., (2004) predicated that intimidation makes employees move away from social environment and information becomes unreachable and lack of communication with others has a negative impact on productivity. Even though Memduhoğlu (2007) states that those who have the power win during mobbing process and weak ones lose, Aubaurg and Moura (2002) founded out that performances of both intimidator and intimidated show a decrease during mobbing process and both parties lose. When all these information and research findings are taken into consideration it is seen that there is an important and significant relationship between organizational depression and mobbing. The findings obtained and results of similar researches confirm that mobbing leads many problems in organizational structure and directly or indirectly harm the organization. One of the variables harming the organization is organizational depression and mobbing in an organization is seen as a serious cause of organizational depression. Organizations should avoid structures creating problems such as mobbing and organizational depression to be effective and productive.

\section{REFERENCES}

[1] Altunışık, R., Coşkun, R., Yıldırım, E. \& Bayraktaroğlu, S.(2002). Research Methods in social Sciences. Sakarya: Sakarya Publishing.

[2] Aras, A. (2012). Relations among mobbing levels, organizatonal commitment and job satisfaction of music teachers working in elementary schools, $\mathrm{PhD}$ thesis, Gazi Universty, Institute of Educational Sciences, Ankara

[3] Arpacioğlu, G. (2003). İşyerindeki Stresin Gizli Kaynağı: Zorbalık ve Duygusal Taciz. Human resources and 
management Journal, November:1-7

[4] Aslan, H., Aslan, D., Göksoy, S. \&Sağır, M. (Mayıs 2014). "Öğretmenlerin Ve Yardımc1 Personelin Örgütsel Depresyona Maruz Kalma Dereceleri” [Bildiri], 9. Ulusal Ĕ̈itim Yönetim Kongresi, Siirt.

[5] Aubourg, G., \& de Moura, H. (2002). Le harcèlement moral. De Vecchi.

[6] Aydın, T. (2010). To study on teachers' ideas about primary schools' administrators' etic leader ship features (Yayımlanmamıs Yüksek Lisans Tezi). İstanbul: Maltepe UniverstySocial Sciences Institute.

[7] Bakan, İ., Taşliyan, M., Taş, F., \& Aka, N. (2014). “Örgüt Depresyonu Ve İs Tatmini Arasındaki İlișki; Bir Üniversitedeki Akademisyenler Üzerinde Alan Araştırması". Kahramanmaraş Sütçü İmam Üniversitesi Iktisadi ve İdari Bilimler Fakültesi Dergisi, 4(01), 295-315.

[8] Beck, A.T. \& Alford, B.A. (2009). Depression: Causes and Treatment. Second edition. University of Pensylvania Press

[9] Bilcgik, G.S. (2000). “Organizational Depression”, H\&HN. Hospitals ve Health Networks, 74 (2): 34-38

[10] Cemaloğlu, N. (2007). Örgütlerin Kaçınılmaz Sorunu: Yıldırma. Ahmet Yesevi Üniversitesi Türk Dünyası Sosyal Bilimler Dergisi-Bilig. Yaz Sayl: 42, s.111-126.

[11] Cemaloğlu, N. (2011). Primary principals' leadership styles, school organizational health and workplace bullying. Journal of Educational Administration, 49(5), 495-512.

[12] Çevik, S.K. (2011). Üniversitelerde öğretim elemanlarının yıldırma (mobbing) davranışlarına maruz kalma düzeyi. Yüksek lisans tezi. Ankara: Hacettepe Üniversitesi Sosyal Bilimler Enstitüsü.

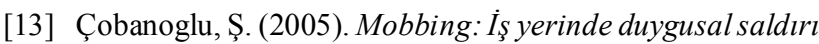
ve mücadele yöntemleri. İstanbul: Timaş Yayınları.

[14] Dökmen, Ü. (2014). Küçük Şeyler "Organizasyonlarda Psikolojik Kontratlar ve Örgüt Depresyonu". İstanbul; Sistem Yayıncilık.

[15] Eğerci, Ç.T. (2009). İlköğretim Okullarında Görev Yapan Ögretmenlerin Maruz Kaldıkları Psikoşiddetin (Mobbingin) Örgütsel Güven Düzeyine Etkisi, Yüksek Lisans Tezi, Sakarya Üniversitesi, Sosyal Bilimler Enstitüsü, Sakarya.

[16] Einarsen, S. (1999). The nature and causes of bullying at work. International Journal of Manpower. Vol 20 (1-2). Retrieved September 8, 2010 from the Web: http://www.ebscohost.com.

[17] Ertürk, A. (2005). Ögrretmen ve okul yöneticilerinin okul ortamında maruz kaldiklarl yıldırma eylemleri. Yayımlanmış Yüksek Lisans Tezi, Gazi Üniversitesi Eğitim Bilimleri Enstitüsü, Ankara.

[18] Griesser, M., Ekman, J. (2005). Nepotistic mobbing behaviour in the Siberian Jar, perisoreus infaustus. Animal Behaviour. Vol. 69, 345-352. Retrieved November 28, 2009 from the Web: http:// www.ebscohost.com.

[19] Gümüştekin, E., G. ve Öztemiz, A., B. (2004), "Örgütsel Stres Yönetimi ve Uçucu Personel Üzerinde Bir Uygulama",Erciyes Üniversitesi İktisadi ve İdari Bilimler Fakültesi Dergisi,Sayı: 23, Temmuz-Aralık, ss. 61-85.
[20] Gündüz, H. B., \& Y1lmaz, Ö. (2008). Ortaöğretim Kurumlarında Mobbing (Yıldırma) Davranışlarına İlişkin Öğretmen ve Yönetici Görüşleri (Düzce İl Örneği). Milli Eğitim Dergisi, 179(2), 269-282.

[21] Hoel, H. Faragher, B., Cooper, C. (2004). Bullying is detrimental to health, but all bullying behaviours are not necessarily equally damaging. British Journal of Guidance \& Councelling, Vol. 32, No.3, p. 367-387.

[22] Kaya, A., Balay, R. ve Göçen, A. (2012). Öğretmenlerin alternatif ölçme ve değerlendirme tekniklerine ilişkin bilme, uygulama ve eğitim ihtiyacı düzeyleri. International of Human Sciences, volume 9, issue 2, year 2012.

[23] Kılınç, A.Ç. (2014). İlköğretim okulu öğretmenlerinin psikolojik dayanıklılık düzeylerinin demografik değişkenler açısından incelenmesi. Turkish Journal of Education, 3(1).

[24] Leymann, H. (1996). The contend and development of mobbing at work. European Journal of Work and Organizational Psychology. Vol. 5 (2), p.165- 184.

[25] Mammadov, E.(2010). Türkiye ve Azerbaycan'dak Ilköğretim Okullarında Görev Yapan Öğretmenlerin Yaşadıkları Yıldırma (Mobbing) Davranışlarının Karşılaştırılması, Yüksek Lisans Tezi, Gazi Üniversitesi, Eğitim Bilimleri Enstitüsü, Ankara.

[26] Memduhoğlu, H. B. (2007). Türk Eğitim Sisteminde Okulların Yönetimi ve Okul Yöneticilerinin Yetiştirilmesi Sorunsalı. Milli Eğitim Dergisi, Sayl: 176.

[27] Moayed, F.A., Daraiesh, N., Shell, R., Salem, s. (2006). Workplace bullying: A review of risk factors and outcomes. Theoretical Issues in Ergonomics Science. Vol. 7 (2), p. 311-327.

[28] Nanto, Z. (2015). Öğretmenlerin yaşadıkları yıldırma durumlarının çeşitli değişkenlere göre incelenmesi. Yüksek lisans tezi. Elazığ: Fırat Üniversitesi Eğitim Bilimleri Enstitüsü.

[29] Okçu, V. (2011). Okul Yöneticilerinin Liderlik Stilleri ile Ögrretmenlerin Örgütsel Băglllıkları ve Yıldırma Yaşama Düzeyleri Arasındaki İlişkilerin Incelenmesi, Doktora Tezi, Gazi Üniversitesi, Eğitim Bilimleri Enstitüsü, Ankara.

[30] Sağır, M. (2015). “Öğretmenlerin Örgütsel Depresyon Ve Mesleki Tükenmișlik Düzeyleri Arasındaki İlișki”. Turkish Journal of Education, 4(3), 29-42.

[31] Sezer, S. (2010). "Bilişsel Davranışçı Yaklaşımla Bütünleştirilen Hobiterapi Uygulamasının Bir Eğitim Kurumunun Örgüt Depresyonu Üzerindeki Etkisi”. Balikesir University Journal of Social Sciences Institute, 13(23), 36-50.

[32] Sezer, S. (2011). “Örgüt Depresyonu Ölçeğinin Geliştirilmesi Ve Psikometrik Niteliklerinin Belirlenmesi”. İş-Güç Endüstri İlişkileri ve Insan Kaynakları Dergisi, 13(1), 39-50.

[33] Tinaz, P. (2006). İşyerinde psikolojik taciz (mobbing). Ankara: Çalışma ve Toplum Dergisi, 2006/4.

[34] Uğurlu, Z. (2015). Türk Eğitim Sistemi ve Okul Yönetimi. Editör: Uğur Akın, Ankara: Pegem Akademi. 
[35] Ural, C.P. (2009). Psikolojik şiddete Maruz Kalmış Öğretmenlerin Ögrenilmiş Çaresizlik Düzeylerinin Incelenmesi, Yüksek Lisans Tezi, Sakarya Üniversitesi, Sosyal Bilimler Enstitüsü, Sakarya.

[36] Yazıcıŏlu, Y. ve Erdoğan, S. (2004). SPSS uygulamalı bilimsel araştırma yöntemleri. Ankara: Detay Yayıncılık

[37] Yılmaz, A., Ekinci, Süleyman (2003), "Örgütsel Yaşamda Depresyonun Kamu Çalışanlarının Performansına Etkileri Üzerine Bir Araştırma”, Yönetim ve Ekonomi, Celal Bayar Üniversitesi, Cilt, 10, Sayl, 2 Manisa. 